\title{
Review of Rare Earth Elements as Fertilizers and Feed Additives: A Knowledge Gap Analysis
}

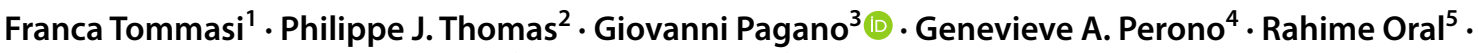 \\ Daniel M. Lyons ${ }^{6} \cdot$ Maria Toscanesi $^{3} \cdot$ Marco Trifuoggi $^{3}$
}

Received: 31 August 2020 / Accepted: 10 October 2020 / Published online: 3 November 2020

(c) The Author(s) 2020

\begin{abstract}
Rare earth elements (REEs) are key constituents of modern technology and play important roles in various chemical and industrial applications. They also are increasingly used in agricultural and zootechnical applications, such as fertilizers and feed additives. Early applications of REEs in agriculture have originated in China over the past several decades with the objective of increasing crop productivity and improving livestock yield (e.g., egg production or piglet growth). Outside China, REE agricultural or zootechnical uses are not currently practiced. A number of peer-reviewed manuscripts have evaluated the adverse and the positive effects of some light REEs (lanthanum and cerium salts) or REE mixtures both in plant growth and in livestock yield. This information was never systematically evaluated from the growing body of scientific literature. The present review was designed to evaluate the available evidence for adverse and/or positive effects of REE exposures in plant and animal biota and the cellular/molecular evidence for the REE-associated effects. The overall information points to shifts from toxic to favorable effects in plant systems at lower REE concentrations (possibly suggesting hormesis). The available evidence for REE use as feed additives may suggest positive outcomes at certain doses but requires further investigations before extending this use for zootechnical purposes.
\end{abstract}

\section{Rare Earth Elements: Technological Tools and Matter of Health Concern}

An overwhelming number of rare earth elements (REE)related technological applications have been developed over the last decade, making these elements indispensable to present day life (Rim et al. 2013; Shin et al. 2019). At

Giovanni Pagano

paganog756@gmail.com

1 Department of Biology, “Aldo Moro” Bari University, 70125 Bari, Italy

2 Environment and Climate Change Canada, Science and Technology Branch, National Wildlife Research Center Carleton University, Ottawa, ON K1A 0H3, Canada

3 Department of Chemical Sciences, Federico II Naples University, 80126 Naples, Italy

4 Department of Obstetrics and Gynecology, McMaster University, Hamilton, ON L8N 3Z5, Canada

5 Faculty of Fisheries, Ege University, 35100 Bornova, İzmir, Turkey

6 Center for Marine Research, Ruđer Bošković Institute, 52210 Rovinj, Croatia the same time, another focus of REE toxicity research has been devoted to their multiple adverse effects in a number of biota, as demonstrated in a growing body of literature (Pagano et al. 2015; d'Aquino and Tommasi 2016; Gwenzi et al. 2018). In a number of reports on REE-associated toxicity, biological effect endpoints, such as growth inhibition, cytogenetic anomalies, or redox abnormalities, have been investigated in plant models (d'Aquino et al. 2009a, b; Thomas et al. 2014; Turra 2018). Compared with that extensive body of literature linking REE exposure to adverse effect in plants (>3000 citations in PubMed), relatively fewer reports have demonstrated positive effects of REEs in promoting plant growth, mainly in field experiments, or in their use as feed additives in livestock. Little information is available on the use of REE-containing fertilizers and their presence and concentrations in soils outside of China. The present review extracted relevant literature linking the keywords "rare earth" with "fertilizer" and "feed additive." The reviewed literature is based on previously available references and recently retrieved from online databases, including PubMed, Embase, Scopus, Web of Science, and Google Scholar. The selected reports showed a complex, yet 
suggestive body of evidence focused on the use of REEs as fertilizers and as feed additives.

\section{REE-Associated Effects on Plant Growth}

The effects of specific elements on the growth processes of plants have long been of interest to agronomists and plant physiologists. An early report by Drobkov (1941) demonstrated that the yield of pea plants was increased by the addition of $10^{-2} \mathrm{~g}$ lanthanum per vessel. After that pioneering study, the agronomic use of REEs became a growing subject of investigation in subsequent decades (Harmet 1979; Wu et al. 1983). This use was further highlighted in a review by Pang et al. (2002) as an established practice in Chinese agriculture. Recent studies, mostly published in the past decade, have focused on laboratory studies, such as the cellular and molecular effects of REEs on a number of plant species. As summarized in Table 1, published studies were mostly focused on $\mathrm{La}, \mathrm{Ce}$, or REE mixtures and their effects on a limited number of plant species. For example, administration of a REE-based fertilizer was shown to increase wheat (Triticum aestivum) crop yield and REE accumulation (Zhang and Shan 2001). Furthermore, by administering a REE mixture to wheat plants (Triticum aestivum) as foliagedressing, Liang et al. (2005) found higher REE accumulation in roots and leaves, while no distinct REE residue in grains was found.

Major REEs, such as La and Ce, can affect uptake and accumulation of nutrient elements, and high concentrations alone or in combination can inhibit root elongation of wheat (Hu et al. 2002). d'Aquino et al. (2009a) treated durum wheat (Triticum durum Desf.) with a REE mixture and found inhibition of seed germination and decrease of

Table 1 Use of REE-based fertilizers and main observed effects on plant growth, plant organ accumulation and soil microorganisms

\begin{tabular}{|c|c|c|}
\hline Plant species & Observed effects & References \\
\hline Wheat (Triticum aestivum) & $\begin{array}{l}\text { Foliage-dressing has a higher accumulation of REEs in } \\
\text { root and leaf. No significant accumulation; no residue of } \\
\text { REEs in grains was found }\end{array}$ & Liang et al. (2005) \\
\hline Triticum durum & $\begin{array}{l}\text { REE nitrate inhibited seed germination at } 0.01 \text { and } \\
0.1 \mathrm{mM} \text {, while pre-soaking for } 2-4 \mathrm{~h} \text { inhibited seed } \\
\text { germination at higher concentrations }\end{array}$ & d'Aquino et al. (2009a) \\
\hline $\begin{array}{l}\text { Corn (Zea mays) and mungbean } \\
\text { (Vigna radiata) }\end{array}$ & $\begin{array}{l}\text { Decreased growth or no effects from exposures to } \mathrm{La} \text { or } \mathrm{Ce} \\
\text { at levels from } 0.2 \text { to } 5 \mathrm{mM}\end{array}$ & Diatloff et al. (2008) \\
\hline Set of native and crop species & $\begin{array}{l}\text { Higher phytotoxicity in native versus crop species in dose- } \\
\text { response tests }\end{array}$ & Thomas et al. (2014) and Carpenter et al. (2015) \\
\hline Soybean (Glycine max) & $\begin{array}{l}\text { Low La concentrations stimulated photosynthetic rate } \\
\text { and chlorophyll content, leading to a higher incidence } \\
\text { of binucleate cells, and to an increase in roots and shoot } \\
\text { biomass. At higher La levels, soybean growth was } \\
\text { reduced }\end{array}$ & de Oliveira et al. (2015) \\
\hline Rice (Oryza sativa) & $\begin{array}{l}\text { La-associated concentration-dependent modulation of oxi- } \\
\text { dative stress endpoints, consistent with hormetic effects }\end{array}$ & $\mathrm{Xu}$ and Chen (2011) and Liu et al. (2016a, b) \\
\hline Rice & $\mathrm{Ce}(25-100 \mu \mathrm{M})$ stimulated rice germination and growth & Ramírez-Olvera et al. (2018) \\
\hline Rice & La positively affects aged seed germination & Fashui et al. (2000) \\
\hline Rice & Ce positively affects aged seed germination & Fashui (2002) \\
\hline Rice & La positively affects seed germination and seedling growth & Fashui et al. (2003) \\
\hline Tea & Cell polysaccharides bound REE sprayied on plants & Wang et al. (2003) \\
\hline Duckweed (Lemna minor) & $\begin{array}{l}\text { Ce }(0.1 \mathrm{mM}) \text { increased growth; } 1 \mathrm{mM} \mathrm{Ce} \text { cau sed oxidative } \\
\text { stress }\end{array}$ & Zicari et al. (2018) \\
\hline Allium сера & $\begin{array}{l}\text { Highest concentration of } \mathrm{La} \text { and } \mathrm{Ce}(200 \mathrm{mg} / \mathrm{kg}) \text { induced } \\
\text { significant decrease in root elongation and mitotic index, } \\
\text { with increased mitotic aberrations }\end{array}$ & Kotelnikova et al. (2019) \\
\hline Allium сера & $\begin{array}{l}\mathrm{CeO}_{2} \text { microparticles and nanoparticles }(12.5-100 \mathrm{ppm}) \text { for } \\
4 \mathrm{~h} \text { had cytotoxic and genotoxic effects }\end{array}$ & Liman et al. (2019) \\
\hline Adzuki bean (Vigna angularis) & $\begin{array}{l}\mathrm{La}^{3+} \text { alleviates P-deficiency, improves photosynthesis and } \\
\text { decreases oxidative stress }\end{array}$ & Lian et al. (2019) \\
\hline Trichoderma strains & $\begin{array}{l}\text { Tolerance to } \mathrm{La}^{3+} \text { and REE mixture, and dose-dependent } \\
\text { effects }\end{array}$ & d'Aquino et al. (2009b) \\
\hline Trichoderma viride, T. hartianum & $\begin{array}{l}\text { La and REE mixture induce inhibitory effects in liquid } \\
\text { cultures }\end{array}$ & Tang et al. (2004) \\
\hline
\end{tabular}


plantlet growth at 0.01-0.1 mM. Higher La and Ce levels $(0.2-5 \mathrm{mM})$ were tested in Zea mays and Vigna radiata by Diatloff et al. (2008) who found that at 1 and $5 \mathrm{mM}$, La and Ce significantly decreased the shoot dry weight of corn and mungbean. The results showed that germination was inhibited by $\mathrm{Ce}$ at low $\mathrm{pH}$, with reductions in biomass for the two native forb species after exposure to all REEs. Moreover, root biomass of native species was affected at lower doses than in crop species. REE uptake by plants was higher in the below-ground parts than in the above-ground plant tissues. In corn (Zea mays), REE accumulation was observed in roots and improved P-uptake and crop yield (Xu and Wang 2007; Emmanuel et al. 2010). The changes in crop production were explained in part by REE-induced changes to antioxidant activity (i.e., peroxidase and superoxide dismutase activity) (Emmanuel et al. 2010). de Oliveira et al. (2015) exposed soybean plants to $\mathrm{La}(5-160 \mu \mathrm{M})$ and found that low La concentrations stimulated photosynthetic rate and chlorophyll content, leading to a higher incidence of binucleate cells and to an increase in root and shoot biomass. At higher La levels, soybean growth was reduced. Indeed, exposure to REEs, particularly La-containing REEs, significantly impacts plant growth and nutrient quality (von Tucher and Schmidhalter 2005; Xiong et al. 2006; Wang et al. 2012; Ren et al. 2016). Wang et al. (2012) found evidence that these effects may be due to DNA breaks and DNA-protein crosslings. Furthermore, it was suggested that REEs can activate endocytosis in plant cells and facilitate REE deposition (Wang et al. 2014). Two other studies (Xu and Chen 2011; Liu et al. 2016a, b) tested the effects of $\mathrm{La}^{3+}(0.05-1.5 \mathrm{mM})$ on reactive oxygen species (ROS) production and antioxidant metabolism in the roots of rice (Oryza sativa). ROS levels declined after treatment with $0.05 \mathrm{mM} \mathrm{La}^{3+}$, and antioxidant metabolism was enhanced. Similar results were found by exposing rice or duckweed to $\mathrm{Ce}$, with an evident shift from stimulating to inhibitory effects by increasing Ce concentrations (RamírezOlvera et al. 2018; Zicari et al. 2018). While the effects of Ce may be species-specific, as measured in eight different plant species, soil properties also can significantly influence the severity of Ce phytotoxicity (Moreira et al. 2019).

A recent report by Kotelnikova et al. (2019) evaluated La and Ce toxicity on onion (Allium cepa) in solutions and amended to soil. The authors found a significant decrease in root elongation and mitotic index, with increased mitotic aberrations, and significant cytotoxicity of soil samples containing the highest $\mathrm{La}$ and Ce concentration $(200 \mathrm{mg} / \mathrm{kg})$. Another recent study of REE-associated toxicity in Allium cepa reported that $\mathrm{CeO}_{2}$ microparticles and nanoparticles (12.5-100 ppm) exerted cytotoxic and genotoxic effects (Liman et al. 2019). In fact, there are reports of $\mathrm{CeO}_{2}$ and other REE $\left(\mathrm{La}_{2} \mathrm{O}_{3}, \mathrm{Gd}_{2} \mathrm{O}_{3}, \mathrm{Yb}_{2} \mathrm{O}_{3}\right)$ nanoparticles inhibiting root elongation in several crop species (Ma et al. 2010). Adzuki bean (Vigna angularis) seedlings were exposed to
$\mathrm{LaNO}_{3}(150 \mathrm{mg} / \mathrm{L})$, and changes in growth, photosynthetic ability, and phosphorus-use efficiency under P-deficiency conditions were concurrently evaluated (Lian et al. 2019). The negative effects of P-deficiency on photosynthetic activity and chlorophyll content in leaves were alleviated by $\mathrm{La}^{3+}$ treatment. In turn, phosphate fertilization and liming were considered to be significant sources of REEs and soils receiving continuously high doses of these inputs are likely to be enriched in REEs (Silva et al. 2019) at concentrations that should be considered under risk assessment frameworks.

REE-associated effects on field trials are very limited. Some data concern the effects of spraying REE fertilizer on tea (Wang et al. 2003). The results of field experiments showed the REE concentrations in new shoots of tea plants and REE concentrations in soil were significantly correlated. Approximately $10 \%$ of soluble REEs in tea infusion was bound to polysaccharide, and the amount of REE-bound polysaccharide decreased over time. At least a 25-day safety interval was needed between spraying and harvesting if the microelement fertilizer was used to enhance tea output and to ensure consumption safety.

Little information is available on the effect of REEs on soil microbiota and the role of microbiota in the balance between the chemical forms and bioavailability of REEs in soil, which may affect their uptake and distribution in plant tissues, as REE mixtures and La affect the growth of some bacteria and fungi (d'Aquino and Tommasi 2016). Soilborne fungi (Trichoderma atroviride, T. harzianum, Botrytis cinerea, Alternaria alternata, Fusarium solani, Rhizoctonia solani, and Sclerotinia sclerotiorum) were found to display an overall good tolerance to the presence of several REEs in the culture medium (d'Aquino et al. 2009b). Growth inhibitory effects were detected in plate tests when La or a REE mixture (containing $\mathrm{La}, \mathrm{Ce}, \mathrm{Pr}, \mathrm{Nd}$, and $\mathrm{Gd}$ ) were supplied at concentrations higher than $100 \mathrm{mM}$. In liquid culture tests, inhibitory effects were observed on the growth of T. atroviride and T. harzianum when exposed to La and REE mixture at concentrations from 1 to $10 \mathrm{mM}$ (Tang et al. 2004). In this study, REE accumulation also had stimulatory effects with concurrent inhibition and restimulation of soil bacteria and actinomycetes, along with a continuous stimulation on soil fungi. The interactions between REEs and microbial cells were influenced by many parameters, such as cell structure and external conditions, as well as ionic availability attesting to the complex inter-relationships of REEs with many ecosystem components (d'Aquino et al. 2009b).

The effects of soil REEs on navel orange quality and safety were investigated by Cheng et al. (2015) in REE mining areas. This study investigated the transfer characteristics of REEs from soil to navel orange pulp (Citrus sinensis Osbeck cv. Newhall) and the effects of soil REE content on the internal fruit quality at concentrations ranging from 38.6 to $546 \mathrm{mg} / \mathrm{kg}$. The REE content in the main 
organs of the navel orange decreased in the following order: root $>$ leaf $>$ peel $>$ pulp. The REE accumulation capacity of navel orange pulp is relatively low, and the REE content in pulp was approximately 14 times lower than the food safety limit set in China (Cheng et al. 2015).

The distribution of 16 REEs (Sc, Y, and 14 lanthanoid elements) in field-grown maize and the concentration of heavy metals in the grains after application of REE-containing fertilizers were studied in treated crops during the vegetation growth stage (Xu et al. 2002). Ten days after REE administration, significant dose-dependent accumulative effects of individual REEs in maize roots and shoots were observed, except for Sc and $\mathrm{Lu}$ (Xu et al. 2002). At the $2 \mathrm{~kg} / \mathrm{ha}$ REE fertilizer levels, accumulative concentrations of light REEs ( $\mathrm{La}, \mathrm{Ce}, \mathrm{Pr}$, and $\mathrm{Nd}$ ) and $\mathrm{Gd}$ in the plant shoots were significantly higher than in controls. Concentrations of individual REEs in field-grown maize after REE administration decreased in the order of root $>$ leaf $>$ stem $>$ grain. During the vegetative growth period, selective accumulation of individual REEs ( $\mathrm{La}, \mathrm{Ce}$ ) in the roots were found in a dynamic equilibrium, and the distribution of these elements in the plants was variable. At a dosage of less than $10 \mathrm{~kg} / \mathrm{ha}$ REEs, no accumulative concentrations of individual REEs were detected in maize grains. Under the experimental conditions, the application of REE-containing fertilizers did not induce increases in REE concentrations in grains. The authors concluded that the REE dosage currently applied in China $(0.23 \mathrm{~kg} / \mathrm{ha} / \mathrm{year})$ can hardly affect the safety of maize grains in arable soils, even over a long period (Xu et al. 2002).

Data concerning the effects of REEs on seed germination are still contradictory. Thomas et al. (2014) reported on the effect of $\mathrm{La}, \mathrm{Y}$, and $\mathrm{Ce}$ on seed germination in selected crop and wild plant species. La and Ce contamination at high $\mathrm{pH}$ had no impact on seed germination in the tested species at any dose, whereas $\mathrm{Ce}$ supplied at low $\mathrm{pH}$ induced negative effects on seed germination in Asclepias syriaca, Panicum virgatum, Raphanus sativus, and Solanum lycopersicum. Yttrium severely affected seed germination in Desmodium canadense and $S$. lycopersicum. The authors suggested that the slow accumulation rate of REEs in the environment could be problematic, even if limited effects have so far been reported on seed germination in different species. Other data reported positive effects of La on germination of aged rice seeds (Fashui 2002; Fashui et al. 2000, 2003). On the other hand, exposure to different REEs in the soil had no effects on the germination of many wild and crop plant species; only $\mathrm{Nd}$ and Er reduced germination in Raphanus sativus and in tomato, respectively. Not clear were the effects of Pr and Sm, which induced negative effects at low but not at high concentrations (Carpenter et al. 2015). A recent review by Agathokleous et al. (2019) focused on REE-associated hormesis, i.e., stimulation of several biological functions exerted by low levels of agents inducing inhibition (toxicity) at higher concentrations. This report critically evaluated the body of literature assessing the hormetic effects of La on plant physiology and found substantial evidence for La-associated hormesis. Following the pioneering study by Stebbing (1982), an extensive number of reports demonstrated the occurrence of hormesis deriving from the effects of a number of physical and chemical agents, including metals (Poschenrieder et al. 2013; Morkunas et al. 2018) and, more specifically, REEs (Nascarella and Calabrese 2016; Liu et al. 2016a, b; Xu and Chen 2011; Ramírez-Olvera et al. 2018; Zicari et al. 2018; Oliveira Duarte et al. 2018). Altogether, the present knowledge of La- and REE-associated hormesis may provide grounds for supporting the use of REEs-at appropriate, growth enhancing concentrations-as fertilizers to boost crop yields, beyond Chinese agriculture, in wider geographical regions. Decision-making should rely on appropriate investigations confirming the lack of REE accumulation in the edible portions of plants that could inadvertently lead to negative health outcomes to secondary consumers (Xu et al. 2002; Liang et al. 2005). Beyond hormesis, REEs have been investigated as essential elements involved in basic biological events, thus raising their biological significance to a number of different biota (Daumann 2019).

Other lines of evidence focused on the REE-associated interferences with adverse events or improvements of plant growth or quality. This was the case for Ce-induced growth enhancement of tomato plants by counteracting Fusarium wilt infection (Adisa et al. 2018, 2020). A complementary finding also was reported by Liang et al. (2006) who found Ce-associated protection of soybean seedlings when exposed to two levels of supplementary UV-B radiation. A study by Ma et al. (2014) evaluated the effects of spray application of $\mathrm{La}$ and $\mathrm{Ce}$ solutions on yield and quality of Chinese cabbage (Brassica chinensis) in different seasons. These authors found that treatments in spring and autumn promoted plant growth, with increased fresh and dry weight ratios of harvested material. Together, the weight of evidence suggests that at appropriate concentrations, positive outcomes in plant growth can be achieved with minimal risk to secondary consumers who eat the fruits and/or grain. As a final consideration, Ren et al. (2016) reported that REE-based fertilizers increased plant growth in both spring and autumn; however, increases for Chinese cabbage were greater in the autumn than in the spring while the opposite was seen for turnips (Brassica napus). Therefore, crop species and growing season should be considered when applying REE fertilizers to crops (Ren et al. 2016).

\section{REEs as Feed Additives in Livestock}

The use of REE preparations as additives in livestock feed has been practiced for several decades (Ji and Cui 1988; Xu et al. 1999) as reviewed by Rambeck and Wehr (2005) 
and by Redling (2006). Recently, the use of REE-based feed additives were reviewed by Squadrone et al. (2018), Abdelnour et al. (2019), and Tariq et al. (2020). Another review by Flachowsky et al. (2019) raised substantial doubts on the effectiveness of REE supplementation in feed additives. The main goals of these zootechnical procedures in poultry were focused on egg yield and improved egg quality by administering REE feed additives to laying hens. Increased growth rate in REE-supplemented chicks, piglets, or ruminants also were sought and discussed by the EFSA Panel on Additives and Products of Substances used in Animal Feed (FEEDAP) (EFSA 2016, 2019) and are summarized in Table 2. The European Commission just enacted the law No. 2020/1370 on October 1, 2020 approving the use of REE citrate "Lancer" feed additive for weaned piglets (Official Journal of the European Union 2020). Before this EC act, an established body of literature had pointed to the use of REE-based feed additives in poultry and pig breeding.

Broiler chicks were tested for growth and feed conversion ratio after administration of REE feed supplements in five independent studies. He et al. (2010) tested the effects of REE citrate or REE chloride at a concentration of $70 \mathrm{mg} / \mathrm{kg}$ and found increased gain in body weight and feed conversion ratio. Similarly, Agbede et al. (2011) found that $\mathrm{La}_{2} \mathrm{O}_{3}$ $(100-300 \mathrm{mg} / \mathrm{kg}$ ) increased total weight gain and altered heart, spleen, and liver weights. Furthermore, REE supplementation led to changes in hematological and nutritional parameters, including total red blood cell count, hemoglobin and differential leukocytes, cholesterol, and bicarbonate (Agbede et al. 2011; Ozung et al. 2019). Two studies (Igbasan and Adebayo 2012; Cai et al. 2015) failed to find increased gain in chick body weight by administering La or $\mathrm{Ce}$ or REE mixtures as feed additives at concentrations ranging from 100 to $1500 \mathrm{mg} / \mathrm{kg}$. These apparently contradictory data might suggest that lower REE doses might be more effective in promoting growth gain than the higher REE concentrations utilized in the latter two studies (He et al. 2001; Igbasan and Adebayo 2012; Cai et al. 2015).

The effects of REE-based feed supplements on laying hens were investigated in terms of egg production and egg quality. A series of studies consistently reported an increase in egg production, along with a decrease in oxidative stress endpoints following administration of $\mathrm{La}$ or Ce oxides or REE mixtures at concentrations ranging from 100 to $1000 \mathrm{mg} / \mathrm{kg}$ (Durmuş and Bölükbaşı 2015; Bölükbaş1 et al. 2016; Cai et al. 2016). Bölükbaşı et al. (2016) found that low-dose of $\mathrm{Ce}$ oxide addition significantly increased serum calcium and phosphorus, paralleling what was found by Reka et al. (2018) in White Leghorn layers. Moreover, feed conversion ratio, egg shelf life, and coefficient of apparent digestibility were found to be increased following REE supplementation. In a related species, Eleraky and Rambeck (2011) tested REE supplementation on growth performance of Japanese quails and found increased weight gain compared with control group with improved feed conversion ratio and efficiency of protein and energy utilization.

Administration of REE-supplemented pig feeds were evaluated in a series of studies in terms of growth performance, feed conversion ratio, and digestibility. Early studies testing supplementation with higher REE dosages (300 mg/ $\mathrm{kg}$ ) reported on increased piglet growth performance (He and Rambeck 2000; He et al. 2001; Schuller et al. 2002; Wang and Xu 2003). This growth-promoting effect of REE- enriched yeast was confirmed by Cai et al. (2018). However, a previous report by Kraatz et al. (2006) failed to find increased growth performance of pigs following feed supplementation with $200 \mathrm{mg} / \mathrm{kg}$ of REE mixture. Furthermore, Förster et al. (2008) found that supplementation with a REE mixture decreased feed intake but increased thyroid hormone levels in rearing piglets. A recent report by Xiong et al. (2019) tested immunity and antioxidant activity in sows and their piglets supplemented with a REE mixture $(200 \mathrm{mg} / \mathrm{kg})$ and found improved antioxidant and immunity both in sows and in piglets.

A more limited body of work focused on the effects of REE feed addition in ruminants. Adu et al. (2006) reported increased weight gain in West African dwarf sheep supplemented with $\mathrm{La}_{2} \mathrm{O}_{3}(100-300 \mathrm{mg} / \mathrm{kg})$, without significant effects on serum and hematological endpoints. Schwabe et al. $(2011,2012)$ supplemented German Holstein bulls with REE citrate (100-300 mg/kg) finding decreased weight gain, but accumulation in liver, kidneys, and rib bone with increasing REE supplementation. Three studies were conducted on ruminally cannulated steers and found improved rumen fermentation and increased digestibility of neutral detergent fiber (Liu et al. 2008; Xun et al. 2014; Lin et al. 2015).

\section{REE-Associated Uses in Agriculture and Zootechny: State-of-the-Art and Prospects}

The body of literature on the uses of REEs as fertilizers and as feed additives in livestock suggests the following outcomes:

1. REE-associated effects in plant models ranged from growth stimulation (hormesis) to inhibitory effects as a function of REE concentration (Poschenrieder 2013; Morkunas et al. 2018; Nascarella and Calabrese 2016; Liu et al. 2016a, b; Xu et al. 2002);

2. Different accumulation gradients were noted in plant and animal organs, with minimal-if any-accumulation in the edible parts (Xu et al. 2002; Tariq et al. 2020); 
Table 2 Use of REE-based feed additives in livestock: observed effects

\begin{tabular}{|c|c|c|c|c|}
\hline Target species/strains & Tested REEs & $\begin{array}{l}\text { REE concen- } \\
\text { tration (mg/ } \\
\mathrm{kg})\end{array}$ & Observed effects & References \\
\hline \multicolumn{5}{|l|}{ 1. Poultry } \\
\hline Ross broiler chicks & REE citrate or REE chloride & 70 & $\begin{array}{l}\text { Increased gain in body weight } \\
\text { and feed conversion ratio }\end{array}$ & He et al. (2010) \\
\hline Arbor Acre broiler chicks & $\mathrm{LaCl}_{3}$ or $\mathrm{La}_{2} \mathrm{O}_{3}$ & $100-400$ & $\begin{array}{l}\text { No significant difference in the } \\
\text { final live weight, daily weight } \\
\text { gain and feed conversion ratio }\end{array}$ & Igbasan and Adebayo (2012) \\
\hline Ross 308 1d-old broilers & REE-enriched yeast & $500-1500$ & $\begin{array}{l}\text { No significant influence on } \\
\text { growth performance, but } \\
\text { improved nutrient digestibility } \\
\text { and meat quality }\end{array}$ & Cai et al. (2015) \\
\hline Lohman LSL laying hens & $\mathrm{La}_{2} \mathrm{O}_{3}$ & $100-400$ & $\begin{array}{l}\text { Significantly increased egg } \\
\text { production; no effect on egg } \\
\text { weight; decreased MDA and } \\
\text { TBARS }\end{array}$ & Durmuş and Bölükbaşı (2015) \\
\hline Lohman LSL laying hens & $\mathrm{CeO}_{2}$ & $100-400$ & $\begin{array}{l}\text { Increased egg production, feed } \\
\text { conversion ratio and egg shelf } \\
\text { life; decreased SOD, MDA } \\
\text { and TBARS }\end{array}$ & Bölükbaşı et al. (2016) \\
\hline ISA brown laying hens & REE-enriched yeast & $500-1000$ & $\begin{array}{l}\text { Significantly increased egg } \\
\text { production and coefficient of } \\
\text { apparent digestibility }\end{array}$ & Cai et al. (2016) \\
\hline Japanese quails & REE citrate & 50-200 & $\begin{array}{l}\text { Improved growth and efficiency } \\
\text { of protein and energy utiliza- } \\
\text { tion }\end{array}$ & Eleraky and Rambeck (2011) \\
\hline \multicolumn{5}{|l|}{ 2. Pigs } \\
\hline Piglets & $\mathrm{La}_{2} \mathrm{O}_{3}$ or REE mixture & 300 & $\begin{array}{l}\text { Gain in body weight increase } \\
\text { and feed conversion ratio }\end{array}$ & $\begin{array}{l}\text { He and Rambeck (2000) and } \\
\text { He et al. (2001) }\end{array}$ \\
\hline $\begin{array}{l}\text { (Landrace } \times \text { York- } \\
\text { shire }) \times \text { Duroc finishing pigs }\end{array}$ & REE-enriched yeast & $500-1500$ & $\begin{array}{l}\text { Improved growth performance, } \\
\text { digestibility, blood lympho- } \\
\text { cyte counts, and fecal Lacto- } \\
\text { bacillus counts }\end{array}$ & Cai et al. (2018) \\
\hline Piglets & REE mixture & 200 & $\begin{array}{l}\text { Growth performance of REE- } \\
\text { citrate and control fed piglets } \\
\text { did not differ significantly }\end{array}$ & Kraatz et al. (2006) \\
\hline Sows and piglets & REE mixture & 200 & $\begin{array}{l}\text { Improved antioxidant effects } \\
\text { and immunity of sows and } \\
\text { piglets }\end{array}$ & Xiong et al. (2019) \\
\hline \multicolumn{5}{|l|}{ 3. Ruminants } \\
\hline West African dwarf sheep & $\mathrm{La}_{2} \mathrm{O}_{3}$ & $100-300$ & $\begin{array}{l}\text { Better daily weight gain } \\
\text { and total weight gain; no } \\
\text { significant effects on serum } \\
\text { and hematological endpoints, } \\
\text { except for significant WBC } \\
\text { increase }\end{array}$ & Adu et al. (2006) \\
\hline German Holstein bulls & REE citrate & $100-300$ & $\begin{array}{l}\text { Decreased weight gain; no } \\
\text { increase in nutrient digest- } \\
\text { ibility }\end{array}$ & Schwabe et al. (2011) \\
\hline $\begin{array}{l}\text { Ruminally cannulated Sim- } \\
\text { mental steers }\end{array}$ & $\mathrm{LaCl}_{3}$ & $450-1800$ & $\begin{array}{l}\text { Improved rumen fermentation } \\
\text { and feed digestion; simulated } \\
\text { digestive microorganisms or } \\
\text { enzymes }\end{array}$ & Liu et al. (2008) \\
\hline $\begin{array}{l}\text { Ruminally cannulated Sim- } \\
\text { mental steers }\end{array}$ & $\mathrm{CeCl}_{3}$ & $80-240$ & $\begin{array}{l}\text { Increased the digestibility } \\
\text { of neutral detergent fibre, } \\
\text { decreased molar ratio of } \\
\text { rumen acetate to propionate }\end{array}$ & Lin et al. (2015) \\
\hline
\end{tabular}


3. REE-based feed additives in poultry failed to result in increased weight gain in broiler chicks, whereas REEsupplemented laying hens improved quantitative and qualitative egg production (Durmuş and Bölükbaş1 2015; Bölükbaş1 et al. 2016; Cai et al. 2016);

4. Growth performance in REE-supplemented piglets appeared to depend on REE dosages, as increased weight gain was observed for REE dosages $>300 \mathrm{mg} /$ $\mathrm{kg}$, and not for a dosage of $200 \mathrm{mg} / \mathrm{kg}$ (He and Rambeck 2000; He et al. 2001);

5. Little, if any, conclusion can be drawn from reports on REE supplementation in ruminants, except for a study of REE feed additive in sheep, resulting in increased weight gain. The published reports focused on cattle and on changes, if any, to rumen function and content.

Altogether, the practices of amending soils or supplementing animal diet with REE, well established in the Chinese agronomic and zootechnical spheres, appear to offer suggestive and stimulating challenges worldwide in terms of achieving improved crop or livestock yield. Rare earth elements could be a potentially important breakthrough in agronomy in a world with increasing food security issues. Further investigations and qualified decision-making based on the presently available and research data are warranted.

Authors Contribution Conceptualization, MT and FT; Writing - Original Draft, GP; Writing - Review \& Editing, FT, GP, and MT; Supervision, PJT and DML.

Funding Open access funding provided by Università degli Studi di Napoli Federico II within the CRUI-CARE Agreement.

\section{Compliance with Ethical Standards}

Conflict of interest The authors declare no conflict of interest.

Open Access This article is licensed under a Creative Commons Attribution 4.0 International License, which permits use, sharing, adaptation, distribution and reproduction in any medium or format, as long as you give appropriate credit to the original author(s) and the source, provide a link to the Creative Commons licence, and indicate if changes were made. The images or other third party material in this article are included in the article's Creative Commons licence, unless indicated otherwise in a credit line to the material. If material is not included in the article's Creative Commons licence and your intended use is not permitted by statutory regulation or exceeds the permitted use, you will need to obtain permission directly from the copyright holder. To view a copy of this licence, visit http://creativecommons.org/licenses/by/4.0/.

\section{References}

Abdelnour SA, Abd El-Hack ME, Khafaga AF, Noreldin AE, Arif M, Chaudhry MT, Losacco C, Abdeen A, Abdel-Daim MM (2019) Impacts of rare earth elements on animal health and production: highlights of cerium and lanthanum. Sci Total Environ 672:10211032. https://doi.org/10.1016/j.scitotenv.2019.02.270

Adisa IO, Reddy Pullagurala VL, Rawat S, Hernandez-Viezcas JA, Dimkpa CO, Elmer WH, White JC, Peralta-Videa JR, GardeaTorresdey JL (2018) Role of cerium compounds in fusarium wilt suppression and growth enhancement in tomato (Solanum lycopersicum). J Agric Food Chem 66:5959-5970. https://doi. org/10.1021/acs.jafc.8b01345

Adisa IO, Rawat S, Pullagurala VLR, Dimkpa CO, Elmer WH, White JC, Hernandez-Viezcas JA, Peralta-Videa JR, Gardea-Torresdey JL (2020) Nutritional status of tomato (Solanum lycopersicum) fruit grown in fusarium-infested soil: impact of cerium oxide nanoparticles. J Agric Food Chem 68:1986-1997. https://doi. org/10.1021/acs.jafc.9b06840

Adu OA, Adeseye SA, Adebiyi OA, Olumide MD, Igbasan FA, Alokan JA (2006) Performance of West African dwarf sheep fed diets supplemented with rare earth elements (REE). J Agr For Social Sci 4:166-174

Agathokleous E, Kitao M, Calabrese EJ (2019) Hormetic dose responses induced by lanthanum in plants. Environ Pollut 244:332-341. https://doi.org/10.1016/j.envpol.2018.10.007

Agbede JO, Arimah AA, Adu OA, Olaleye MT, Aletor VA (2011) Growth-enhancing, health impact and bacteria suppressive property of lanthanum supplementation in broiler chicken. Arch Zootech 14:44-56.

Bölükbaşı SC, Al-Sagan AA, Ürüşan H, Erhan MK, Durmuş O, Kurt $\mathrm{N}$ (2016) Effects of cerium oxide supplementation to laying hen diets on performance, egg quality, some antioxidant enzymes in serum and lipid oxidation in egg yolk. J Anim Physiol Anim Nutr (Berl) 100:686-693. https://doi.org/10.1111/jpn.12429

Cai L, Park YS, Seong SI, Yoo SW, Kim IH (2015) Effects of rare earth elements-enriched yeast on growth performance, nutrient digestibility, meat quality, relative organ weight and excreta microflora in broiler chickens. Livest Sci 172:43-49. https:// doi.org/10.1016/j.livsci.2014.11.013

Cai L, Nyachoti CM, Hancock JD, Lee JY, Kim YH, Lee DH, Kim IH (2016) Rare earth element-enriched yeast improved egg production and egg quality in laying hens in the late period of peak egg production. J Anim Physiol Anim Nutr (Berl) 100:492-498. https://doi.org/10.1111/jpn.12376

Cai L, Nyachoti CM, Kim IH (2018) Impact of rare earth elementenriched yeast on growth performance, nutrient digestibility, blood profile, and fecal microflora in finishing pigs. Can J Anim Sci 98:347-353. https://doi.org/10.1139/cjas-2017-0089

Carpenter D, Boutin C, Allison JE, Parsons JL, Ellis DM (2015) Uptake and effects of six rare earth elements (REEs) on selected native and crop species growing in contaminated soils. PLoS ONE 10:e0129936. https://doi.org/10.1371/journal.pone.01299 36

Cheng J, Ding C, Li X, Zhang T, Wang X (2015) Rare earth element transfer from soil to navel orange pulp (Citrus sinensis Osbeck cv. Newhall) and the effects on internal fruit quality. PLoS ONE 10:e120618. https://doi.org/10.1371/journal.pone.0120618

d'Aquino L, Tommasi F (2016) Rare earth elements and microorganisms. In: Pagano G (ed) Rare earth elements in human and environmental health: at crossroads between toxicity and safety. Pan Stanford Publishing Pte. Ltd, Singapore, pp 117-131. ISBN 978-981-4745-00-0

d'Aquino L, Morgana M, Carboni MA, Staiano M, Vittori Antisari M, Re M, Lorito M, Vinale F, Abadi KM, Woo SL (2009a) Effect of some rare earth elements on the growth and lanthanide accumulation in different Trichoderma strains. Soil Biol Biochem 41:2406-2413. https://doi.org/10.1016/j.soilb io.2009.08.012

d'Aquino L, de Pinto MC, Nardi L, Morgana M, Tommasi F (2009b) Effect of some light rare earth elements on seed germination, 
seedling growth and antioxidant metabolism in Triticum durum. Chemosphere 75:900-905. https://doi.org/10.1016/j.chemospher e.2009.01.026

Daumann LJ (2019) Essential and ubiquitous: the emergence of lanthanide metallobiochemistry. Angew Chem Int Ed Engl 58:1279512802. https://doi.org/10.1002/anie.201904090

de Oliveira C, Ramos SJ, Siqueira JO, Faquin V, de Castro EM, Amaral DC, Techio VH, Coelho LC, e Silva PH, Schnug E, Guilherme LR (2015) Bioaccumulation and effects of lanthanum on growth and mitotic index in soybean plants. Ecotoxicol Environ Saf 122:136144. https://doi.org/10.1016/j.ecoenv.2015.07.020

Diatloff E, Smith FW, Asher CJ (2008) Effects of lanthanum and cerium on the growth and mineral nutrition of corn and mungbean. Ann Bot 101:971-982. https://doi.org/10.1093/aob/mcn021

Drobkov AA (1941) Influence of cerium, lanthanum, and samarium on development of peas. C R Acad Sci URSS 32:669-670

Durmuş O, Bölükbaşı ŞC (2015) Biological activities of lanthanum oxide in laying hens. J Appl Poultry Res 24:481-488. https://doi. org $/ 10.3382 / \mathrm{japr} / \mathrm{pfv} 052$

EFSA (2016) Safety of lancer (lanthanide citrate) as a zootechnical additive for weaned piglets. EFSA J 14:4477. https://doi. org/10.2903/j.efsa.2016.4477

EFSA (2019) Safety of lancer (lanthanide citrate) as a zootechnical additive for weaned piglets. EFSA J 17:5912. https://doi. org/10.2903/j.efsa.2019.5912

Eleraky AW, Rambeck W (2011) Study on performance enhancing effect of rare earth elements as alternatives to antibiotic feed additives for Japanese quails. J Am Sci 7:211-215

Emmanuel ESC, Anandkumar B, Natesan M, Maruthamuthu S (2010) Efficacy of rare earth elements on the physiological and biochemical characteristics of Zea mays L. Aust J Crop Sci 4:289-294

Fashui H (2002) Study on the mechanism of cerium nitrate effects on germination of aged rice seed. Biol Trace Elem Res 87:191-200. https://doi.org/10.1385/BTER:87:1-3:191

Fashui H, Zhenggui W, Guiwen Z (2000) Effect of lanthanum on aged seed germination of rice. Biol Trace Elem Res 75:205-213. https ://doi.org/10.1385/BTER:75:1-3:205

Fashui H, Ling W, Chao L (2003) Study of lanthanum on seed germination and growth of rice. Biol Trace Elem Res 94:273-286. https:// doi.org/10.1385/BTER:94:3:273

Flachowsky G, Bampidis V, Zhao G, Grün M, Meyer U (2019) Rare earth elements (REE) as feed additives in animal nutrition. CAB Rev 14:046. https://doi.org/10.1079/PAVSNNR201914046

Förster D, Berk A, Hoppen HO, Rambeck WA, Flachowsky G (2008) A note on the effect of rare earth elements on the performance and thyroid hormone status of rearingpiglets. J Anim Feed Sci 17:70-74. https://doi.org/10.22358/jafs/66471/2008

Gwenzi W, Mangori L, Danha C, Chaukura N, Dunjana N, Sanganyado E (2018) Sources, behaviour, and environmental and human health risks of high- rare earth elements as emerging contaminants. Sci Total Environ 636:299-313. https://doi.org/10.1016/j. scitotenv.2018.04.235

Harmet KH (1979) Rapid growth responses of Avena coleoptile segments to lanthanum and other cations. Plant Physiol 64:1094-1098

He ML, Rambeck WA (2000) Rare earth elements-a new generation of growth promoters for pigs. Arch Anim Nutr 53:323-334. https ://doi.org/10.1046/j.1439-0396.2001.00327.x

He ML, Ranz D, Rambeck WA (2001) Study on performance enhancing effect of rare earth elements in growing and fattening pigs. $\mathrm{J}$ Anim Physiol Anim Nutr (Berl) 85:263-270. https://doi.org/10.1 046/j.1439-0396.2001.00327.x

He ML, Wehr U, Rambeck WA (2010) Effect of low doses of dietary rare earth elements on growth performance of broilers. J Anim Physiol Anim Nutr (Berl) 94:86-92. https://doi.org/10.1016/10.1 111/j.1439-0396.2008.00884.x
Hu X, Ding Z, Chen Y, Wang X, Dai L (2002) Bioaccumulation of lanthanum and cerium and their effects on the growth of wheat (Triticum aestivum L.) seedlings. Chemosphere 48:621-629. https ://doi.org/10.1016/s0045-6535(02)00109-1

Igbasan FA, Adebayo OS (2012) Growth response, carcass quality, some haematological and biochemical parameters of broiler chickens fed on diets supplemented with lanthanum salts. Int J Sci Eng Res 3:1-17

Ji YJ, Cui MZ (1988) Toxicological studies on safety of rare earths used in agriculture. Biomed Environ Sci 1:270-276

Kotelnikova A, Fastovets I, Rogova O, Volkov DS, Stolbova V (2019) Toxicity assay of lanthanum and cerium in solutions and soil. Ecotoxicol Environ Saf 167:20-28. https://doi.org/10.1016/j. ecoenv.2018.09.117

Kraatz M, Taras D, Männer K, Simon O (2006) Weaning pig performance and faecal microbiota with and without in-feed addition of rare earth elements. J Anim Physiol Anim Nutr (Berl) 90:361-368. https://doi.org/10.1111/j.1439-0396.2005.00594.x

Lian H, Qin C, Zhang L, Zhang C, Li H, Zhang S (2019) Lanthanum nitrate improves phosphorus-use efficiency and tolerance to phosphorus-deficiency stress in Vigna angularis seedlings. Protoplasma 256:383-392. https://doi.org/10.1007/s00709-018-1304-3

Liang T, Zhang S, Wang L, Kung HT, Wang Y, Hu A, Ding S (2005) Environmental biogeochemical behaviors of rare earth elements in soil-plant systems. Environ Geochem Health 27:301-311. https ://doi.org/10.1007/s10653-004-5734-9

Liang CJ, Huang XH, Zhou Q (2006) Effect of cerium on photosynthetic characteristics of soybean seedling exposed to supplementary ultraviolet-B radiation. J Environ Sci (China) 18:1147-1151. https://doi.org/10.1016/s1001-0742(06)60053-3

Liman R, Acikbas Y, Ciğerci İH (2019) Cytotoxicity and genotoxicity of cerium oxide micro and nanoparticles by Allium and Comet tests. Ecotoxicol Environ Saf 168:408-414. https://doi. org/10.1016/j.ecoenv.2018.10.088

Lin SX, Wei C, Zhao GY, Zhang TT, Yang K (2015) Effects of supplementing rare earth element cerium on rumen fermentation, nutrient digestibility, nitrogen balance and plasma biochemical parameters in beef cattle. J Anim Physiol Anim Nutr (Berl) 99:1047-1055. https://doi.org/10.1111/jpn.12295

Liu Q, Wang C, Huang YX, Dong KH, Yang WZ, Wang H (2008) Effects of lanthanum on rumen fermentation, urinary excretion of purine derivatives and digestibility in steers. Anim Feed Sci Technol 142:121-132. https://doi.org/10.1080/17450390802327761

Liu D, Zheng S, Wang X (2016a) Lanthanum regulates the reactive oxygen species in the roots of rice seedlings. Sci Rep 6:31860. https://doi.org/10.1038/srep31860

Liu YY, Wang RL, Zhang P, Sun LL, Xu J (2016b) Involvement of reactive oxygen species in lanthanum-induced inhibition of primary root growth. J Exp Bot 67:6149-6159. https://doi. org/10.1093/jxb/erw379

Ma Y, Kuang L, He X, Bai W, Ding Y, Zhang Z, Zhao Y, Chai Z (2010) Effects of rare earth oxide nanoparticles on root elongation of plants. Chemosphere 78:273-279. https://doi.org/10.1016/j.chemo sphere.2009.10.050

Ma JJ, Ren YJ, Yan LY (2014) Effects of spray application of lanthanum and cerium on yield and quality of Chinese cabbage (Brassica chinensis $\mathrm{L}$ ) based on different seasons. Biol Trace Elem Res 160:427-432. https://doi.org/10.1007/s12011-014-0062-0

Moreira CG, de Carvalho TS, de Oliveira C, de Abreu LB, de Castro ACS, Ribeiro PG, Bispo FHA, Boutin C, Guilherme LRG (2019) Ecological risk assessment of cerium for tropical agroecosystems. Chemosphere 221:124-131. https://doi.org/10.1016/j.chemospher e.2018.12.195

Morkunas I, Woźniak A, Mai VC, Rucińska-Sobkowiak R, Jeandet P (2018) The role of heavy metals in plant response to biotic stress. Molecules 23:E2320. https://doi.org/10.3390/molecules23092320 
Nascarella MA, Calabrese EJ (2016) Hazard assessment and the evaluation of rare earth element dose-response relationships. In: Pagano G (ed) Rare earth elements in human and environmental health: At crossroads between toxicity and safety. Pan Stanford Ltd., Singapore, pp 184-194. ISBN 978-981-4745-00-0

Official Journal of the European Union (2020) Commission Implementing Regulation (EU) L 319/5 of 1 October 2020

Oliveira Duarte AC, de Oliveira C, Junio Ramos S, de Castro EM, Siqueira JO, Guilherme LRG (2018) Lanthanum content and effects on growth, gas exchanges, and chlorophyll index in maize plants. Acta Scient Biol Sci 40:38469. https://doi.org/10.4025/ actascibiolsci.v40i1.38469

Ozung PO, Oko OOK, Henry AJ, Jimmy NP, Eburu PO, Etim CD (2019) Influence of dietary lanthanum oxide $\left(\mathrm{La}_{2} \mathrm{O}_{3}\right)$ on the blood characteristics and ovarian morphometry of broiler chickens. Nig J Anim Prod 46:40-46.

Pagano G, Guida M, Tommasi F, Oral R (2015) Environmental effects and toxicity mechanisms of rare earth elements-knowledge gaps and research prospects. Ecotoxicol Environ Saf 115C:40-48. https ://doi.org/10.1016/j.ecoenv.2015.01.030

Pang X, Li D, Peng A (2002) Application of rare-earth elements in the agriculture of China and its environmental behavior in soil. Environ Sci Pollut Res Int 9:143-148. https://doi.org/10.1007/ BF02987462

Poschenrieder C, Cabot C, Martos S, Gallego B, Barceló J (2013) Do toxic ions induce hormesis in plants? Plant Sci 212:15-25. https ://doi.org/10.1016/j.plantsci.2013.07.012

Rambeck WA, Wehr U (2005) Use of rare earth elements as feed additives in pig production. Pig News Inf $26: 41 \mathrm{~N}-47 \mathrm{~N}$

Ramírez-Olvera SM, Trejo-Téllez LI, García-Morales S, Pérez-Sato JA, Gómez-Merino FC (2018) Cerium enhances germination and shoot growth, and alters mineral nutrient concentration in rice. PLoS ONE 13:e0194691. https://doi.org/10.1371/journ al.pone.0194691

Redling K (2006) Rare earth elements in agriculture with emphasis on animal husbandry. Dissertation Thesis, Veterinary Faculty, Ludwig-Maximilians-Universität München

Reka D, Thavasiappan V, Selvaraj P, Arivuchelvan A (2018) Effect of dietary REE supplementation on blood biochemical parameters in layer chicken. Int J Curr Microbiol Appl Sci 7:181-185. https ://doi.org/10.20546/ijcmas.2018.701.020

Ren Y, Ren X, Ma J, Yan L (2016) Effects of mixed rare earth fertilizer on yield and nutrient quality of leafy vegetables during different seasons. J Rare Earth 34:638-643. https://doi.org/10.1016/S1002 -0721(16)60073-X

Rim KT, Koo KH, Park JS (2013) Toxicological evaluations of rare earths and their health impacts to workers: a literature review. Saf Health Work 4:12-26. https://doi.org/10.1007/10.5491/ SHAW.2013.4.1.12

Schuller S, Borger C, He ML, Henkelmann R, Jadamus A, Simon O, Rambeck WA (2002) The effectiveness of rare earth elements as a possible alternative growth promoter for pigs and poultry. Berliner und Munchener tierarztliche Wochenschrift 115:16-23

Schwabe A, Meyer U, Flachowsky G, Dänicke S (2011) Effect of graded levels of rare earth elements in diets of fattening bulls on growing and slaughtering performance, and on nutrient digestibility of wethers. Arch Anim Nutr 65:55-73. https://doi. org/10.1080/1745039x.2010.520408

Shin S-H, Kim H-O, Rim KT (2019) Worker safety in the rare earth elements recycling process from the review of toxicity and issues. Saf Health Work 10:409-419. https://doi.org/10.1016/j. shaw.2019.08.005

Silva FBV, Nascimento CWA, Alvarez AM, Araújo PRM (2019) Inputs of rare earth elements in Brazilian agricultural soils via P-containing fertilizers and soil correctives. J Environ Manag 232:90-96. https://doi.org/10.1016/j.jenvman.2018.11.031
Squadrone S, Stella C, Brizio P, Abete MC (2018) A baseline study of the occurrence of rare earth elements in animal feed. Water Air Soil Pollut 229:190. https://doi.org/10.1007/s11270-018-3825-y

Stebbing AR (1982) Hormesis: the stimulation of growth by low levels of inhibitors. Sci Total Environ 22:213-234

Tang X, Sun Y, Xia M, Wen C, Zhang Z (2004) Ecological effects of low dosage mixed rare earth elements accumulation on major soil microbial groups in a yellow cinnamon soil. Ying Yong Sheng Tai Xue Bao 15:2137-2141

Tariq H, Sharma A, Sarkar S, Ojha L, Pal RP, Mani V (2020) Perspectives of rare earth elements as feed additive in livestock: a review. Asian-Australas J Anim Sci 33:373-381. https://doi.org/10.5713/ ajas. 19.0242

Thomas PJ, Carpenter D, Boutin C, Allison JE (2014) Rare earth elements (REEs): effects on germination and growth of selected crop and native plant species. Chemosphere 96:57-66. https:// doi.org/10.1016/j.chemosphere.2013.07.020

Turra C (2018) Sustainability of rare earth elements chain: from production to food-a review. Int J Environ Health Res 28:23-42. https://doi.org/10.1080/09603123.2017.1415307

von Tucher S, Schmidhalter U (2005) Lanthanum uptake from soil and nutrient solution and its effects on plant growth. J Plant Nutr Soil Sci 168:574-580. https://doi.org/10.1002/jpln.200520506

Wang MQ, Xu ZR (2003) Effect of supplemental lanthanum on the growth performance of pigs. Asian-Australas J Anim Sci 16:1360-1363. https://doi.org/10.5713/ajas.2003.1360

Wang D, Wang C, Ye S, Qi H, Zhao G (2003) Effects of spraying rare earths on contents of rare Earth elements and effective components in tea. J Agric Food Chem 51:6731-6735. https://doi. org/10.1021/jf0303417

Wang C, Zhang K, He M, Jiang C, Tian L, Tian Y, Wang X (2012) Mineral nutrient imbalance, DNA lesion and DNA-protein crosslink involved in growth retardation of Vicia faba L. seedlings exposed to lanthanum ions. J Environ Sci 24:214-220. https:// doi.org/10.1016/S1001-0742(11)60760-2

Wang L, Li J, Zhou Q, Yang G, Ding XL, Li X, Cai CX, Zhang Z, Wei HY, Lu TH, Deng XW, Huang XH (2014) Rare earth elements activate endocytosis in plant cells. Proc Natl Acad U S A 111:12936-12941. https://doi.org/10.1073/pnas.1413376111

Wu Z, Tang X, Tsui C (1983) Studies on the effect of rare earth elements on the increasement of yield in agriculture. J Chin Rare Earth Soc 1:70-75

Xiong SL, Xiong ZT, Chen YC, Huang H (2006) Interactive effects of lanthanum and cadmium on plant growth and mineral element uptake in crisped-leaf mustard under hydroponic conditions. J Plant Nutr 29:1889-1902. https://doi.org/10.1080/0190416060 0899485

Xiong Y, Pang J, Lv L, Wu Y, Li N, Huang S, Feng Z, Ren Y, Wang J (2019) Effects of maternal supplementation with rare earth elements during late gestation and lactation on performances, health, and fecal microbiota of the sows and their offspring. Animals (Basel) 9:E738. https://doi.org/10.3390/ani9100738

$\mathrm{Xu}$ QM, Chen H (2011) Antioxidant responses of rice seedling to $\mathrm{Ce}^{4+}$ under hydroponic cultures. Ecotoxicol Environ Saf 74:1693-1699. https://doi.org/10.1016/j.ecoenv.2011.04.005

Xu X, Wang Z (2007) Phosphorus uptake and translocation in fieldgrown maize after application of rare earth-containing fertilizer. J Plant Nutr 30:557-568. https://doi.org/10.1080/0190416070 1209287

Xu Z, Wang M, Chen L (1999) Growth response of pigs fed supplemental lanthanum and approach of mechanism. J Chin Rare Earth Soc 17:53-59

Xu X, Zhu W, Wang Z, Witkamp GJ (2002) Distributions of rare earths and heavy metals in field-grown maize after application of rare earth-containing fertilizer. Sci Total Environ 293:97-105. https:// doi.org/10.1016/s0048-9697(01)01150-0 
Xun W, Shi L, Hou G, Zhou H, Yue W, Zhang C, Zhang Y (2014) Effect of rare earth elements on feed digestibility, rumen fermentation, and purine derivatives in sheep. Ital J Anim Sci 13:3205. https://doi.org/10.4081/ijas.2014.3205

Zhang S, Shan XQ (2001) Speciation of rare earth elements in soil and accumulation by wheat with rare earth fertilizer application. Environ Pollut 112:395-405
Zicari MA, d'Aquino L, Paradiso A, Mastrolitti S, Tommasi F (2018) Effect of cerium on growth and antioxidant metabolism of Lemna minor L. Ecotoxicol Environ Saf 163:536-543. https://doi. org/10.1016/j.ecoenv.2018.07.113 